UDC 338.45:658.5

D. Palekhov ${ }^{1}$, Cand. Sc. (Law.), PhD (Env. Sc.), orcid.org/0000-0001-6041-668X,

L. Palekhova ${ }^{2}$, Cand. Sc. (Econ.), Assoc. Prof., orcid.org/0000-0003-0217-5755
DOI: $10.29202 /$ nvngu/2018/22

1-Brandenburg University of Technology Cottbus - Senftenberg, Cottbus, Germany, e-mail: dmitry.palekhov@b-tu.de 2 - National Mining University, Dnipro, Ukraine, e-mail: palehovall@gmail.com

\title{
METHODICAL APPROACHES TO INCREASING THE ENERGY EFFICIENCY OF GLOBAL VALUE CHAINS
}

Purpose. The purpose of the presented research is the development of a methodical approach to increasing the energy efficiency along global value chains (GVCs), while including into them new players from countries with weak energy sustainability.

Methodology. The main arguments in the article are developed by analysing official EU documents, statistical reports from international non-governmental organisations, and scientific publications on the subject of energy efficiency in the context of sustainable development, through comparative analysis of statistics in the area of energy consumption, energy efficiency and economic growth in various regions and countries, and by analysing experience of different countries in this field, with particular focus on Germany.

Findings. The study clarified the specific features of the modern concept of energy efficiency which is based on three core dimensions-energy security, energy equity, and environmental sustainability. This concept was considered as the basis for further development of GVCs, as an approach for assessing energy efficiency of their links, and for planning appropriate joint actions. The analysis also showed that integration of businesses from vulnerable economies into the multilateral trading system will help to build and improve the potential for energy efficiency and energy sustainability in them. However, GVCs should be supported by the technologically advanced countries, such as Germany, through technology transfer and strengthening of trade relations in order to be energy reliable and efficient in the long-term perspective.

Originality. Based on the conducted review, several recommendations were made on increasing energy efficiency in GVCs, while taking into consideration the different level of capacity among the partners: 1) it is important to balance strategic priorities and necessary trade-offs for the formation of energy efficient GVCs; 2) differentiation between producers following or not following principles of sustainability in their business practices can be made, in particular, with the help of various voluntary sustainability standards; 3 ) representatives of developed countries should apply a variety of methods for stimulating interest among their prospective partners in sustainable technologies and products.

Practical value. Research findings can be used by companies to develop strategies of their incorporation into GVCs, as well as for making strategic public policy decisions at the local and national levels.

Keywords: energy efficiency, global value chains, energy management, sustainable development, sustainable development goals

Introduction. Since the last two decades national businesses have been getting increasingly involved into global economic processes. Individual operations and various activities aimed at manufacturing of the end products (e.g. research and development, production of components and assembly, marketing and service, etc.) are becoming a part of international economic cooperation and specialisation, which leads to expansion of global value chains (hereinafter GVCs). In this context, the G20 Leaders Declaration (Los Cabos, 2012) stated that today GVCs became a dominating business mechanism [1].

The context of sustainable development in global production and trade processes is of particular concern for national governments, world forums and various international and regional organisations. And, in line with this, energy efficiency has been recognised as a key action field for achieving sustainability in global value chains and procurement networks, which are critical foundations for promoting inclusive and sustainable economic growth, building resilient infrastructure and

(C) Palekhov D., Palekhova L., 2018 industrial sector, making cities safe and sustainable, provision of quality communal services for all, as well as combating climate change and mitigating its impacts.

Analysis of the recent research. In July 2014, OECD, WTO and World Bank published a joint report, in which it was argued that modern GVCs can stimulate development of trade, investments and innovation in related economies. At the same time, countries and companies do not facilitate the implementation of sustainable development goals in the same way [2]. In this regard, the G20 Leaders' Communiqué on Antalya Summit (15-16 November 2015) emphasised the importance of the progress in global supply chains and that there is a need in practical 'flanking' efforts to ensure the openness and inclusiveness of GVCs [3]. The Paris Agreement on climate change adopted in December 2015 became an unprecedented political success [4]. This Agreement marks a decisive turning point in situation of energy sustainability, especially in countries with fragile economies and serious environmental problems. During the World Future Energy Summit 2016 in Abu Dhabi, the former UN Secretary-General Ban Ki-moon stressed that increasing energy efficiency and expanding the use of re- 
newable energy sources should be thought of as a basis for the transformation of the world economy [5].

Unsolved aspects of the problem. The energy policy of G20 defines targeted interventions aimed at increasing energy efficiency, improving the quality and reliability of energy services, as well as enhancing environmental performance of the energy sector. At the same time, it has another priority objective, which brings the overall discussion to a new level of complexity - energy efficiency on a global level. Since 2015 the G20 pursues a policy aimed at sustainable development of global production and distribution processes, ensuring a more extensive integration of the developing countries and countries with economies in transition. This is generally a group of countries with a wide technological gap compared to developed countries and low value addition. These countries can be characterised by vulnerable and fragile economies, having both an inefficient use and/or a high share of fossil fuels, in particular coal, in the energy mix, while their governments and business do not have sufficient financial resources for the large-scale realisation of energy reforms in the context of sustainable development.

International forums and organisations, academia and civil society are engaged in a serious dispute over satisfactory solution to this dilemma. Among other efforts, the World Bank initiated a number of research projects focusing on energy efficiency in GVCs and incorporating private sector concerns in the least developed countries. A report on participation of Burundi in the energy global value chain and on capacity building and skill development in its private sector is just one of many examples [6]. The OECD was also responsible for a wide range of projects to provide policy-makers with a better understanding of sustainable development instruments in the framework of GVCs and new energy policy. For instance, the 2015 report Overcoming Barriers to International Investment in Clean Energy contained an overview of the solar PV and wind energy GVCs, discussed possible solutions for technology transfer and innovation across the value chain with an emphasis on emerging economies.

A certain contribution to the discussion of the problem is made by regular conferences organised in the framework of international university Network for Energy Supply and Energy Efficiency (NESEFF). During the 2015 Network meeting in Baku, Azerbaijan, its participants discussed a number of issues relating to responsible production in the energy sector, implementation of the international energy management systems standard (ISO 50001:2011) in the industrial sector of countries with economies in transition, etc. The following meeting in 2016 in Cottbus, Germany, emphasised the particular significance of the role played by universities and e-learning platforms in promoting the vision of energy efficiency [7-8]. Given the multi-dimensional nature of the formulated problem, it is important to make the debate on this subject a continuously ongoing process.

Objectives of the article. This paper aims to provide a methodical approach to increasing the energy efficiency of GVCs that involve businesses from countries with transitional or backward economies. The main research objectives include the following: 1) specify the concept of energy efficiency in the context of sustainable development goals; 2) analyse the role of Germany in promoting the energy efficiency in GVCs; 3) suggest general measures for balancing and maintaining energy efficiency for sustainable development along GVCs based on principle of their accessibility for developing and transitional economies.

Methods. Applied methods include the following: analysis of the official EU documents, statistical reports from international non-governmental organisations, and scientific publications on the subject of energy efficiency in the context of sustainable development; comparative analysis of statistics in the area of energy consumption, energy efficiency and economic growth in various regions and countries; as well as analysis of the experience of different countries in this field, with a particular focus on Germany.

Presentation of the main research. The context of sustainable development expands understanding of energy efficiency by transferring the issue from narrow preoccupation with some technological, technical and economic perspectives into concrete strategies to promote sustainable development for all, in particular the developing world. The integration of businesses from vulnerable economies into multilateral trading systems will contribute to developing the potential of energy efficiency and energy sustainability in them [9-10].

Emergence of the Energy Trilemma Concept. During the latter half of the twentieth century, it was realised that economic development is often related to and demonstrates its devastating effect on the environment. The rapid growth in production caused significant increase in energy consumption without any regard for the future. It became apparent that traditional energy sources (mainly oil, gas and coal) are finite, while there is a high level of dependency on fossil fuels. The World Energy Council (hereinafter WEC), a UN-accredited global energy body, asserted that "...rising oil and gas demand, if unchecked, would accentuate the consuming countries' vulnerability to a severe supply disruption and resulting price shock" [11]. Growth in fossil fuel production and increase in coal consumption for electricity generation, which are inherently risky, have led to major technological accidents and environmental degradation and at least - considerably contributed to the global climate change. Natural and man-made disasters are often intensified by the lack of a balanced state policy and misbehaviour of business, particularly in developing countries [12].

The further concern is a tremendous inequity in the distribution of access to energy resources, and an unfair concentration of the rights to use them as a source of income. Analysts estimated that $10.6 \%$ of the world's population consume about $55 \%$ of oil and $40.3 \%$ of the total energy; about $80 \%$ of the population consume $21.9 \%$ of oil and $28.7 \%$ of energy [13]. The reality and the possible scale of this conflict are sensed not only by the developing countries, but they threaten to the Euro- 
pean policy of sustainable development and competitiveness of its economy [14].

The modern concept of energy efficiency, which is necessary for achieving UN's sustainable development goals, was in development over the course of many years. In 1993, the WEC published the results of a unique research - Energy for Tomorrow's World: The Realities, the Options and the Agenda for Achievement. The document set out to reconcile global views on the energy issues confronting the world and highlighted the key issues for continued energy development into the $21^{\text {st }}$ century.

In 2000, the WEC published another landmark report - Energy for Tomorrow's World - Acting Now! It provided detailed analysis and discussion reflecting on global trends impacting the energy sustainability. Close attention was given to presentation of three key energy goals to be accomplished by 2020: a) energy accessibility - the provision of reliable and affordable modern energy services; b) energy availability - the quality, reliability, and continuity of energy supply; c) energy acceptability - producing and using energy resources in a manner that gains public acceptance and preserves the environment. Strategies for achieving these goals include 10 policy actions relevant for policy-makers, governments, businesses, energy companies, and energyrelated institutions. Several of these actions can be considered as particularly important for achieving energy sustainability in the format of GVCs, including the following: reap the benefits of market reform and appropriate regulation; keep all energy options open; promote greater energy efficiency; foster financing partnerships linked to environmental goals; fund research, development and deployment; make ethics a strong component of energy system governance, etc.

Energy efficiency, which is an essential prerequisite for the success of sustainability mission, requires reliable ways to properly assess the energy sustainability of business sector and the country, compare the energy sustainability with that of others, and to measure progress towards achievement of the targets. To that end, WEC jointly with Oliver Wyman and the Global Risk Centre of its parent Marsh \& McLennan Companies have developed concept of 'Energy Trilemma' [15]. This concept is based on three core dimensions - energy security, energy equity, and environmental sustainability (Fig. 1).

The achievement of energy security requires the effective management of energy supply, the reliability of

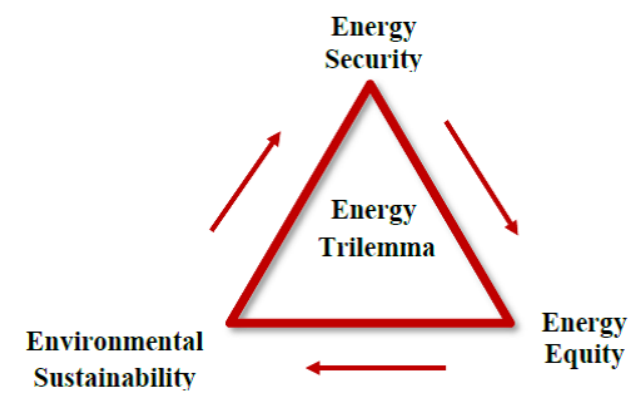

Fig. 1. The energy trilemma concept by WEC [15] energy infrastructure, and the responsibility of energy companies operation to meet current and future demand.

Energy equity provides the accessibility and affordability of the energy supply to household and business consumers. Environmental sustainability is supported through clean technologies and cleaner production practices, reduction of the emissions of pollutants and greenhouse gases, the transition to renewable energy, the solution of the waste problem and conservation of natural habitats.

These three goals include complex interwoven links between governments, business actors and public bodies, economic and social factors, environmental concerns and attitudes towards natural resources, individual producer responsibility and consumer behaviours.

In 2010, the Energy Charter Strategy Group discussed steps to reduce the energy efficiency gap between best technologies of western countries and the existing practices of developing countries and many countries that formerly had centrally planned economies. The trilemma should become the basis for the formation of energy-efficient GVCs.

The Role of German Companies in Increasing the Energy Efficiency in Global Value Chains. Following a long consultation process, the European Commission published in January 2007 the decision to develop a common energy policy - Energy for a Changing World: The New European Energy Policy, which has been approved at a meeting of the European Council on 8-9 March 2007. The document confirmed the global strategy which through a 'post-industrial revolution' shall lead to achieving a 'zero-waste', energy efficient and lowcarbon economy, as well to improved security of energy supply and employment prospects in the EU. The implementation of this concept was subsequently initiated by adopting two legislation 'packages' on climate and energy. The first package covers the period up to 2020 [16], the second relates to the period of 20202030 [17].

Nonetheless, in 2011, WEC in its report Policies for the Future stated: "Perfect alignment in all three dimensions of energy sustainability is a goal no country has yet been able to successfully achieve" [18]. And as of 2016, in the Ranking of Energy Trilemma Index, nine out of ten lead countries are highly industrialised countries of Europe, except New Zealand (Table 1).

In this context, it should be taken into account that objectives of energy efficiency and sustainable development cannot be achieved only through efforts of individual high-tech companies, countries or regions. The transition to energy efficient GVCs means the requirement to find ways for significant reductions in greenhouse gas emissions across the whole life cycle through application of eco-efficiency principles, and substitution of traditional materials with less energy-intensive materials. Of course, different regions, countries and groups of countries all have different experience and challenges in the field of energy efficiency, and have different levels of commercial and technological readiness to sustainable development. 
Table 1

Energy-efficiency profile of countries, 2016*

\begin{tabular}{|c|c|c|c|c|c|c|c|}
\hline \multirow[b]{2}{*}{ Country } & \multirow{2}{*}{$\begin{array}{c}\text { Index } \\
\text { rank }\end{array}$} & \multicolumn{3}{|c|}{ Country rankings } & \multirow{2}{*}{$\begin{array}{l}\text { Industrial } \\
\text { sector } \\
\text { (\% of GDP) }\end{array}$} & \multirow{2}{*}{$\begin{array}{l}\text { GDP per } \\
\text { capita, } \\
\text { PPP US\$ }\end{array}$} & \multirow{2}{*}{$\begin{array}{c}\text { Energy } \\
\text { Intensity } \\
\text { (koe per US\$) }\end{array}$} \\
\hline & & $\begin{array}{l}\text { Energy } \\
\text { Security }\end{array}$ & $\begin{array}{l}\text { Energy } \\
\text { Equity }\end{array}$ & $\begin{array}{l}\text { Environmental } \\
\text { Sustainability }\end{array}$ & & & \\
\hline Denmark & 1 & 1 & 10 & 6 & 22.5 & 46635 & 0.07 \\
\hline Switzerland & 2 & 12 & 2 & 3 & 26.3 & 60535 & 0.05 \\
\hline Sweden & 3 & 10 & 27 & 8 & 26.0 & 46420 & 0.09 \\
\hline Netherlands & 4 & 9 & 3 & 42 & 21.2 & 48459 & 0.07 \\
\hline Germany & 5 & 7 & 15 & 31 & 30.3 & 47268 & 0.07 \\
\hline France & 6 & 16 & 9 & 11 & 19.4 & 39678 & 0.07 \\
\hline Norway & 7 & 29 & 29 & 4 & 38.2 & 61472 & 0.07 \\
\hline Finland & 8 & 3 & 24 & 71 & 26.5 & 40601 & 0.13 \\
\hline New Zealand & 9 & 13 & 20 & 36 & - & 36982 & 0.10 \\
\hline Austria & 10 & 20 & 6 & 23 & 28.0 & 47824 & 0.08 \\
\hline Slovenia & 12 & 2 & 25 & 44 & 33.1 & 31122 & 0.09 \\
\hline Slovakia & 16 & 15 & 18 & 30 & 33.6 & 28877 & 0.08 \\
\hline Czech Republic & 19 & 14 & 5 & 54 & 38.0 & 32167 & 0.09 \\
\hline Azerbaijan & 26 & 23 & 47 & 18 & 58.3 & 17740 & 0.06 \\
\hline Poland & 36 & 60 & 28 & 64 & 32.6 & 26135 & 0.08 \\
\hline Russian Federation & 45 & 6 & 42 & 116 & 35.8 & 24451 & 0.16 \\
\hline Ukraine & 63 & 28 & 61 & 108 & 25.4 & 7916 & 0.19 \\
\hline Armenia & 69 & 84 & 65 & 78 & 28.6 & 8394 & 0.11 \\
\hline Serbia & 73 & 61 & 73 & 89 & 29.8 & 13482 & 0.10 \\
\hline Kazakhstan & 82 & 65 & 54 & 122 & 36.0 & 25877 & 0.12 \\
\hline
\end{tabular}

${ }^{*}$ Prepared using data from Ranking of Energy Trilemma Index on 125 countries calculated by the World Energy Council [15]. Highlighted rows indicate countries participating in the international network NESEFF $\mid$ koe $=$ kilogram of oil equivalent

For example, the energy trilemma of Germany is excellently balanced in comparison to countries with transitional economies (Fig. 2). Since many years its policy was aimed at sustainability and focused on overall reduction in primary energy use and $\mathrm{CO}_{2}$ emissions, and on increasing electricity generation from renewable sources. For example, already in 1991 Germany began promoting renewable electricity using high feed-in tariffs stipulated by the Federal Electricity Feed-in Act (Stromeinspeisungsgesetz or StrEG).

Being a country widely recognised as a leader in promoting sustainable development values and because its economy is very much oriented towards exports, Germany is particularly interested in the development of

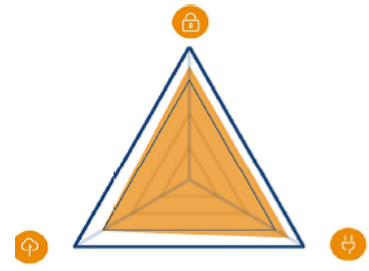

Germany

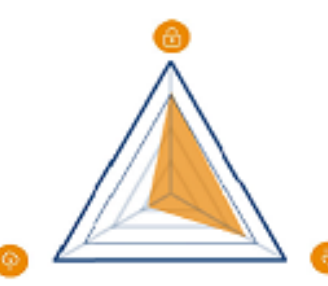

Ukraine
Fig. 2. Germany energy profile in relation to Ukraine [15] energy efficient GVCs. The country implements its mission through significant investments to accelerate appropriate research and development, demonstration and diffusion of renewable energy technologies and environmentally friendly technologies. Today, Germany is the third largest exporter in the world (after China and the US), including high value added or high-technology products accounting for approximately $50 \%$ of export sales (Table 2).

Due to the use of the most modern technologies and implementation of energy management schemes, Germany's companies are at the top of quality and reliability standards on the market of energy efficient products and services. The largest German concerns and corporations have their branches, production and research facilities around the world. There is no doubt that automotive concerns Volkswagen, BMW, Daimler, chemical companies Bayer, BASF, Henkel Group, conglomerate Siemens, energy giants E.ON and RWE make a big contribution to improving energy efficiency and environmental sustainability along value chains. According to the E.ON CEO Johannes Teyssen: "Global trends like sustainability and climate protection, digitalisation and technological innovation are creating a new energy world, in which renewable energy generation, innovative energy 
Table 2

Structure of Germany's exports, in U.S. dollars, 2016 (Calculated from data [20])

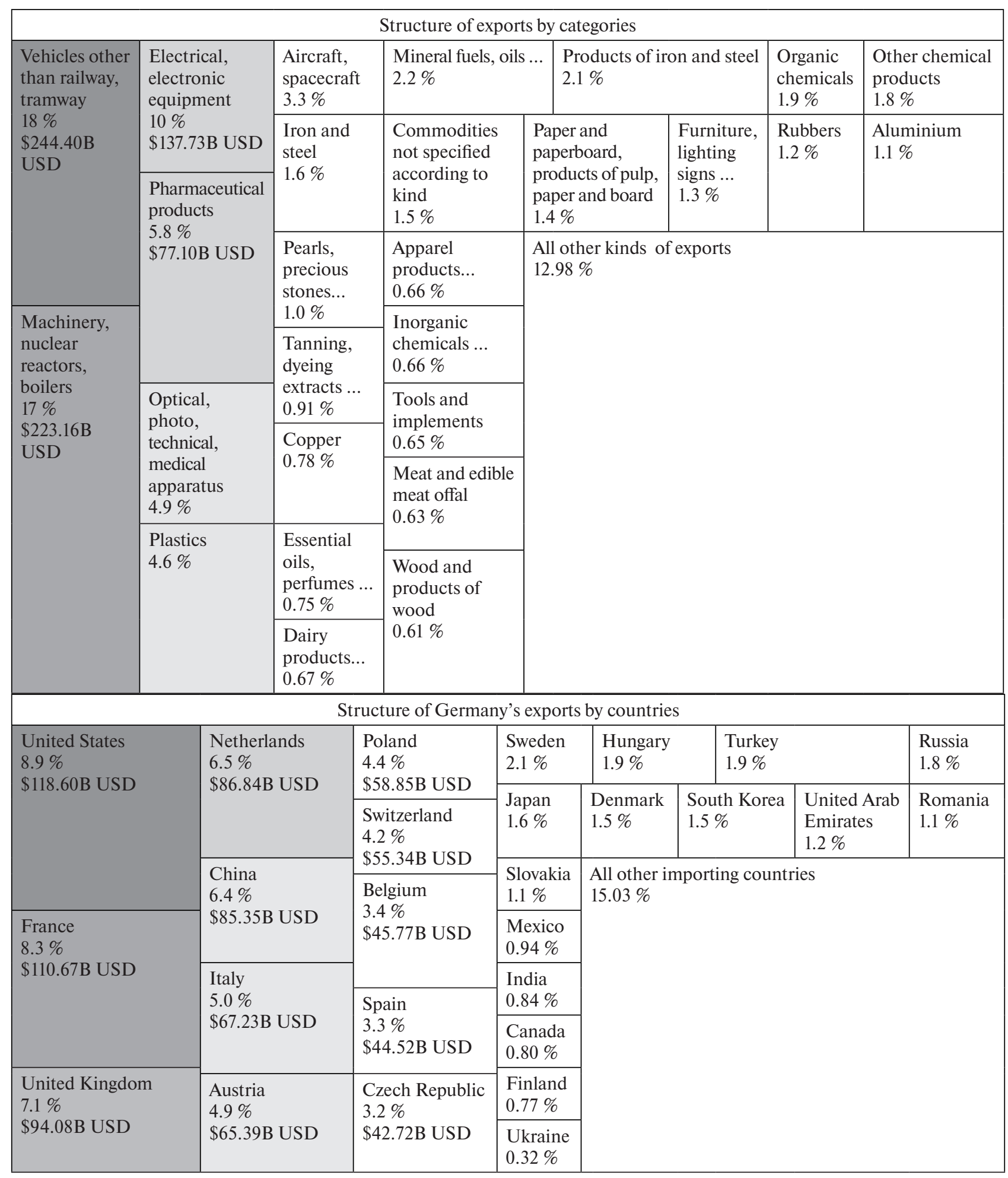

solutions and smart energy networks become indispensable" [19].

However, technologically advanced countries, such as US, France, United Kingdom, Netherlands, China, etc., remain so far the main importers of high-technology products from Germany.

At the same time, to make a breakthrough in energy efficiency, it is important to put a greater emphasis on export of high technologies to countries that are new members of the EU and that have entered association agreements with the EU, such as Serbia and Ukraine. As of now the share of German exports to these countries is quite low (Table 2). In this respect, the German Committee on Eastern European Economic Relations calls the South-Eastern Europe as a 'veritable locomotive of growth'. And the number of stable trade relations and 
cooperation projects with this region is growing. For example, during 2016 Germany's exports to Ukraine grew by $31 \%$, totalling US\$ 4.28 Billion at year-end. This is definitely very helpful for Ukraine's diversification strategies. The environmental sustainability is the weakest link in the country's trilemma. Ukraine's energy sector faces great challenges, ranging from a high dependence on expensive fossil fuel imports such as oil and gas, to inefficient infrastructure and markets. Recent energy policy developments include the decision to replace Russian natural gas with Ukrainian coal, to increase own oil and gas production, to develop nuclear power capacity and promote renewable energy sources. Also representatives of developed countries share the view that ITC should actively identify and promote promising market opportunities for environmentally friendly export products.

Conclusions and recommendations for further research. The study reviewed the transformation of the concept of energy efficiency, which is an essential prerequisite for achieving UN's sustainable development goals. The discussion showed that energy efficiency of GVCs was explicitly recognised as a political, economic and social imperative. Transition to sustainable development cannot rely solely on partnership (economic, political, scientific and other) between technologically developed states. The integration of businesses from vulnerable economies into the multilateral trading system will help to build and improve the potential for energy efficiency and energy sustainability in them. Special attention needs to be accorded to new EU members and countries that have entered into association agreements with the EU, such as Serbia and Ukraine.

The new concept of energy efficiency is based on three core dimensions - energy security, energy equity, and environmental sustainability. This trilemma should be the basis for further expansion of GVCs, as a mechanism for assessing the energy efficiency of all links in them and for planning appropriate joint actions. Such efforts should be supported by the technologically advanced countries, such as Germany, through technology transfer and strengthening of trade relations. Studies have shown that the share of high-tech exports to these countries is currently quite insignificant. However, for the new market to function in the long-term certain preconditions need to be created that will encourage investment and development.

Based on the review in this paper it is possible to make several suggestions that, if taken together, will help to make the goal of increasing energy efficiency across of GVCs more realistic, considering the varying levels of capacity among the partners:

1. It is important to balance strategic priorities and necessary trade-offs for the formation of energy efficient GVCs, in which all parties and interested organisations would be more inclined to enter new markets for products, services and investments in the field of energy efficiency.

2. Developing countries will need to modernise their national legislation and utilise appropriate leverages for minimising imports from countries and producers relying on unfair competition practices, as well as for reduc- ing imports from unsustainable producers. Differentiation between producers following or not following principles of sustainability in their business practices can be made, in particular, with the help of various voluntary sustainability standards.

3. Representatives of developed countries should use a variety of methods to develop interest among their prospective partners in sustainable technologies and products, i.e. through popularisation of their advanced technologies, sharing their experience with and economic benefits of the modern energy management practices, discussion and common search for solutions of problems with achieving energy efficiency, etc.

4. The German experience with market-oriented instruments and regulatory measures for promoting energy-saving technologies should be reviewed, generalised and adapted to accelerate the reforms in countries with poor energy performance, such as Ukraine.

\section{References.}

1. G20 Leaders Declaration, 2012. Overview of summit documents since 2008. In: 2012 Los Cabos Summit, 18-19 June 2012, Mexico [online]. Available at: <https: //www.g20.org/Webs/G20/EN/G20/Summit_documents/summit_documents.htm $>$ [Accessed 20 December 2017].

2. Rapporteur's report: Global Forum on Trade, 11-12 February 2014. In: Trade and Agriculture Directorate, OECD [pdf]. Available at: <http://www.oecd.org/tad/ events/ OECD-tad-rapporteurs-report-global-forumtrade-2014.pdf $>$ [Accessed 28 November 2017].

3. Council of the European Union, 2015. G20 Leaders' Communiqué, Antalya summit, 15-16 November 2015 [online]. Available at: <http://www.consilium.europa. eu/en/press/press-releases/2015/11/16-g20-summitantalya-communique/> [Accessed 15 December 2017]. 4. United Nations Climate Change, 2015. Paris Agreement. Adopted on 12 December 2015 at the twenty-first session of the Conference of the Parties to the United Nations Framework Convention on Climate Change held in Paris from 30 November to 13 December 2015 [online]. Available at: <http://unfccc.int/paris_agreement/ items/9485.php $>$ [Accessed 08 January 2018].

5. UN Secretary-General, 2016. UN Secretary-General's remarks to the World Future Energy Summit, 18 January 2016, Abu Dhabi, United Arab Emirates [online]. Available at: <https://www.un.org/sg/ en/content/sg/ statement/2016-01-18/secretary-generals-remarksworld-future-energy-summit> [Accessed 10 January 2018].

6. Bamber, P., Guinn, A. and Gereffi, G., 2014. Burundi in the Energy Global Value Chain: Skills for Private Sector Development. Center on Globalization, Governance and Competitiveness, Duke University. DOI: 10.13140/ RG.2.1.2211.5925.

7. Palekhov, D., 2016. Teaching about Sustainability at Higher Education Institutions. In: Simon, S., ed., 2016. Der Fakultät Maschinenbau, Elektro- und Energiesysteme Gus- und Osteuropatag Neseff-Netzwerktreffen 2016. Brandenburgische Technische Universität CottbusSenftenberg, pp. 114. 
8. Steinert, C., Leptien, E. and Palekhov, D., 2016. Introduction to the Eco-Campus Elearning Platform. In: Simon, S., ed., 2016. Ingenieurtag 2016. Der Fakultät Maschinenbau, Elektro- und Energiesysteme Gus- und Osteuropatag Neseff-Netzwerktreffen 2016. Brandenburgische Technische Universität Cottbus-Senftenberg, pp. 64-68.

9. Palekhov, D. and Kizilova, M., 2016. Methods for Achieving Energy Efficiency Targets: Analysis of Experience in the EU. Bulletin of the Pridneprovsk State Academy of Building and Architecture, 3(216), pp. 34-41.

10. Palekhova, L. and Simon, S., 2016. Competitive Advantages through the Implementation of International Energy Management Standards. Bulletin of the Pridneprovsk State Academy of Building and Architecture, 3(216), pp. 42-51.

11. European Commission, 2007. Energy for a Changing World: The New European Energy Policy. Speech at the EU Energy Law and Policy conference. Brussels, 25 January 2007 [online]. Available at: <http://europa.eu/ rapid/press-release_SPEECH-07-38_en.htm $>$ [Accessed 27 October 2017].

12. Shvetz, V., Palekhova, L., Simon, S., Palekhov, D. and Mammadov, A., 2015. Convergence of Energy Efficiency Policies in the EU and Countries with Economies in Transition. Socio-Economic and Environmental Problems of the Mining Industry, Building and Energetics. Tula State University, pp. 398-405.

13. Kontorovich, A. E., 2014. The mad, mad, mad, mad world: The future of global energy. Science first hand [online], 1(37), pp. 30-49. Available at: <https://elibrary.ru/ item.asp? id=23182970 $>$ [Accessed 12 January 2018].

14. International Energy Agency, 2015. World Energy Outlook Special Report [pdf]. Available at: <https:// www.iea.org/publications/ freepublications/publication/WEO2015SpecialReportonEnergyandClimateChange.pdf> [Accessed 14 November 2017].

15. World Energy Trilemma. World Energy Council [online]. Available at: < https://www.worldenergy.org/workprogramme/strategic-insight/assessment-of-energy-climate-change-policy/> [Accessed 15 February 2018].

16. Office of the European Union, 2011. Energy 2020: A strategy for competitive, sustainable and secure energy. DOI: $10.2833 / 78930$.

17. EUR-Lex, 2014. Communication from the Commission to the European Parliament, the Council, the European Economic and Social Committee and the Committee of the Regions. A policy framework for climate and energy in the period from 2020 to 2030 (COM/2014/015 final) [online]. Available at: <https://eur-lex.europa. e u / l e g a 1 - c o n t e n t / E N / A L L / ? u r i = CELEX:52014DC0015> [Accessed 15 February 2018].

18. Policies for the future, 2011. Assessment of country energy and climate policies. World Energy Council, London [online]. Available at: <https://www.worldenergy. org/wpcontent/uploads/2012/10/PUB_wec_2011_assessment_of_energy_and_climate_policies_2011_ WEC.pdf [Accessed 19 September 2017].

19. Amelang, S. and Wettengel, J., 2016. E.ON shareholders ratify energy giant's split. A Factsheet on Clean
Energy Wire [online]. Available at: <https://www. cleanenergywire.org/factsheets/eon-shareholders-ratify-energy-giants-split> [Accessed 20 October 2017].

20. United Nations COMTRADE database on international trade. Economic Indicators for Germany - Exports [online]. Available at: <https://tradingeconomics. com/germany/ exports $>$ [Accessed 12 January 2018].

\section{Методичні підходи до підвищення енергоефективності у глобальних ланцюгах створення вартості}

\section{Д. Палєхов ${ }^{1}$, Л. Л. Палєхова ${ }^{2}$}

1 - Бранденбурзький технічний університет Коттбус Зенфтенберг, м. Коттбус, Німеччина, e-mail: dmitry. palekhov@b-tu.de

2 - Державний вищий навчальний заклад „Національний гірничий університет“, м. Дніпро, Україна, е-mail: palehovall@gmail.com

Мета. Розробка методичного підходу до підвищення енергоефективності у глобальних ланцюгах створення вартості, у тому числі для залучення до них нових гравців із країн зі слабкою енергетичною сталістю.

Методика. Основні аргументи були розроблені шляхом аналізу офіційних документів $\mathrm{EC}$, статистичних звітів міжнародних неурядових організацій і вивчення наукових статей із проблем енергоефективності в контексті сталого розвитку, а також порівняльного аналізу досвіду щодо забезпечення енергоефективності та економічного зростання в різних регіонах і країнах, зокрема Німеччини.

Результати. У дослідженні були уточнені особливості сучасної концепції енергоефективності, заснованої на трьох основних аспектах: енергетична безпека, енергетична справедливість і екологічна стійкість. Ця концепція розглядалася як основа для подальшого розширення глобальних ланцюгів створення вартості, як механізм оцінки енергоефективності їхніх ланок і планування відповідних спільних дій. Аналіз також показав, що інтеграція підприємств з уразливих країн у багатосторонню торговельну систему може примножити та удосконалити їхній потенціал енергоефективності та енергетичної стійкості. Однак глобальні ланцюги створення вартості повинні підтримуватися технологічно розвиненими країнами, такими, наприклад, як Німеччина, за допомогою передачі технологій і зміцнення торговельних відносин, щоб бути надійними та ефективними в довгостроковій перспективі.

Наукова новизна. На основі огляду було зроблено кілька пропозицій з метою підвищення можливостей досягнення цілей енергоефективності в рамках глобальних мереж створення вартості з урахуванням різних рівнів потенціалу партнерів: 1) важливо збалансувати стратегічні пріоритети й необхідні компроміси для формування енергоефективних ланцюгів створення вартості; 2) необхідна диференціація між виробниками, які дотри- 
муються або не дотримуються принципів сталості у своїй діловій практиці, що може здійснюватися, зокрема, за допомогою добровільних стандартів сталості; 3) представники розвинених країн повинні використовувати різні методи для стимулювання інтересу у своїх потенційних партнерах до сталих технологій і продуктів.

Практична значимість. Результати дослідження можуть бути використані підприємствами для розробки стратегій залучення до глобальної виробничо-торговельної мережі, а також для прийняття державних стратегічних рішень на місцевому й національному рівнях.

Ключові слова: енергоефективність, глобальні ланцюги створення вартості, енергетичний менеджмент, сталий розвиток, цілі сталого розвитку

\section{Методические подходы к повышению энергоэффективности в глобальных цепях создания стоимости}

\section{Д. Палехов ${ }^{1}$, Л. Л. Палехова ${ }^{2}$}

1 - Бранденбургский технический университет Коттбус - Зенфтенберг, г. Коттбус, Германия, e-mail: dmitry. palekhov@b-tu.de

2 - Государственное высшее учебное заведение „Национальный горный университет“, г. Днепр, Украина, e-mail: palehovall@gmail.com

Цель. Разработка методического подхода к повышению энергоэффективности в глобальных цепях создания стоимости, в том числе для вхождения в них новых игроков из стран со слабой энергетической устойчивостью.

Методика. Основные аргументы были разработаны на основе анализа официальных документов EC, статистических отчетов международных неправительственных организаций и изучения научных статей по проблеме энергоэффективности в контексте устойчивого развития, а также сравнительного анализа имеющегося опыта в области энергоэффективности и экономического роста в различных регионах и странах, в частности, Германии.

Результаты. В исследовании были уточнены особенности современной концепции энергоэффективности, базирующейся на трех принципиальных аспектах: энергетическая безопасность, энергетическая справедливость и экологическая устойчивость. Эта концепция рассматривалась как основа для дальнейшего расширения глобальных цепей создания стоимости, как механизм оценки энергоэффективности их звеньев и планирования соответствующих совместных действий. Анализ также показал, что интеграция предприятий из уязвимых стран в многостороннюю торговую систему может приумножить и усовершенствовать их потенциал энергоэффективности и энергетической устойчивости. Однако глобальные цепи создания стоимости должны поддерживаться технологически развитыми странами, такими, например, как Германия, посредством передачи технологий и укрепления торговых отношений, чтобы быть надежными и эффективными в долгосрочной перспективе.

Научная новизна. На основе обзора было сделано несколько предложений с целью повышения возможностей достижения энергоэффективности в рамках глобальных цепей создания стоимости с учетом разного уровня потенциала партнеров: 1) важно сбалансировать стратегические приоритеты и необходимые компромиссы для формирования энергоэффективных цепей создания стоимости; 2) необходима дифференциация между производителями, которые следуют или не следуют принципам устойчивости в своей деловой практике, что может осуществляться, в частности, с помощью добровольных стандартов устойчивости; 3) представители развитых стран должны использовать различные методы для стимулирования интереса у своих потенциальных партнерах к устойчивым технологиям и продуктам.

Практическая значимость. Результаты исследований могут быть использованы для разработки предприятиями стратегий вхождения в глобальные производственно-сбытовые цепи, а также для принятия государственных стратегических решений на местном и национальном уровнях.

Ключевые слова: энергоэффективность, глобальные иепи создания стоимости, энергетический менеджмент, устойчивое развитие, цели устойчивого развития

Рекомендовано до публікації докт. техн. наук П.І.Пономаренком. Дата надходження рукопису 18.12.17. 